\title{
Questions for Clinton's inauguration
}

Next Wednesday's ceremony in Washington is bound to be an uplifting and even moving ceremony, but not all of the new president's hankerings for change are to be equally keenly awaited.

INAUGURATION days in the United States are mostly memorable occasions. They should be, for the changing of the guard in the United States must eventually affect us all. There will be an inauguration day next week, on Wednesday, when Mr Bill Clinton takes over from President George Bush. By then, Clinton will have no doubt had time, in the breathing space after November's hectic election, to string together in a brief speech several phrases that will stick in the world's mind - "there is nothing to fear but fear itself" and the like. Unlike his predecessor, Clinton has a way with words (and we must hope that his laryngitis allows him to make them heard), so that will be the easy part. What comes afterwards will be more difficult.

Even so, it matters that Clinton should strike the right note next Wednesday. The US President differs in a subtle way from the heads of other elected governments in that he (or, yet, she) is also elected leader. The president commands not merely the armed forces, but also a large measure of loyalty and support among the American people - Clinton's way of referring to his electors during the election campaign. So a new incumbent can strike out in a new direction and be reasonably sure that he will be followed, at least for a time. New presidents know that, but too often respond by promising at their inauguration that they will, in return, secure 'leadership' for the United States. Bush offered that in plenty four years ago, without quite saying what he meant.

Clinton must avoid that trap. To ask that is not to diminish either the achievement or the promise of the United States. How could that be when the surviving superpower dutifully sought United Nations sanction for its organization of the war in the Gulf in 1991, and now seems ready to be the world's policeman for a time? Or when Jefferson's doctrine of "life, liberty and the pursuit of happiness" seems, for the time being, to have infected even its previous enemies? The United States is now also the chief source of new knowledge, both in science and in other fields of scholarship; will not great things flow from that? But the world has, thank goodness, become a more complicated and thus more interesting place. Leadership is not what it needs, but more generalized cleverness. Beating Japan (and, next decade, South China) at consumer electronics might seem like leadership, but would be a distraction.

The cautious part of Clinton has not yet declared himself on science, and on scholarship generally, except to confirm his predecessors' ambition that the workforce should be well educated. True, he has made an excellent nomination for his chief science adviser (see Nature 361, 2; 1993); John Gibbons, if he is given the authority, could restore the tradition that his office takes a broad view of its terms of reference the Strategic Defense Initiative as well as the Superconducting Super Collider and the success rate of research grant applications to the National Institutes of Health. It will help that Gibbons now knows the Capitol and its people as well as he does. Strike one to Clinton.

The worry is what the new president has been saying about international trade and domestic employment under the rubric of 'competitiveness' - Washington's word for the state of US industry since President Carter's time. There is no reason why Clinton should follow Reagan and Bush (and their quondam cheerleaders in Britain) by letting the market decide how many people have useful and gainful jobs, but there are serious risks in trying to accelerate the conversion of seed-corn into full-grown corn plants, not the least of which is the temptation to cut back on the seed producers, or to keep telling them what kinds of seeds to produce. One of the achievements of the past decade in the United States has been a substantial growth of the basic research enterprise. With patience, this will yield profit and prosperity. Impatience, and an undiscriminating zest for change, could hazard that.

\section{Rothschild revisited?}

Industry's record on research casts doubt on pleas to fund British science on a 'purchaser-provider' basis.

WHEN in 1971 the late Lord Rothschild proposed putting publicly funded applied research on a "customer-contractor' basis, he met a barrage of protests from the scientific community. These subsided as it became clear that the principle would not be applied to fundamental research. Where the applications of Rothschild's ideas have broken down, however, has been in the failure of 'contracting' government departments to follow his prescription that they should also contribute to the long-term goals of the contracting research agencies.

Is history now repeating itself? The Advisory Council on Science and Technology (ACOST) has now suggested to William Waldegrave, the cabinet minister responsible for science, that the Rothschild principle be developed into a new 'purchaser-provider' basis for all 'mission-orientated' 